\title{
組合せ荷重を受けるパイプの最終強度 (その1)
}

一一曲げ，外圧㘧よび軸力を受ける海底パイプラインの崩壊強度解析——

$\begin{array}{lllllll}\text { 正員 } & \text { 藤 } & \text { 田 } & \text { 譲* } & \text { 正員 野 本 敏 治* } \\ \text { 正員 } & \text { 榎 } & \text { 沢 } & \text { 誠* } & & & \end{array}$

Ultimate Strength of Pipes Subjected to Combined Loads (1 st Report)

- Analytical Study of the Collapse Strength of Submarine Pipelines under Combined

Bending, External Pressure and Axial Force-

by Yuzuru Fujita, Member Toshiharu Nomoto, Member

Makoto Enosawa, Member

\section{Summary}

Submarine pipelines which transport oil and gas are now being installed or planed for more and more deep waters. It was reported that planed crossing includes a Norweigian Trench crossing with depth to $350 \mathrm{~m}$ and trans-Mediterranean crossing with depth to $2,000 \mathrm{~m}$. Submarine pipelines to be installed at such depths will require the utmost care in engineering design.

During a pipelaying operation, the pipe is subjected to the combined loads of bending, tension and external pressure. Considering the fact that bending stress during installation often reach the yield range, even though DNV Rules allow $0.2 \%$ residual longitudinal strain, it implies that this bending may become a collapse initiator. Furthermore, it should be considered that initial deformation reduce the resistance of pipeline against collapse, especially in deep water.

A rigorous analytical treatment of the collapse strength of pipeline during installation is very complicated, because it is a function of loading conditions as well as $D / t$ ratios, material properties, and initial deformation.

In this paper a simplified analytical method, which was proposed by authors for evaluating the ultimate strength of stiffend plate, is extended in order to estimate the collapse strength of pipeline under the action of combined bending, axial force and external pressure, including the effect of initial out-of-roundness.

The present method is compound of two parts. One is elastic analysis based on energy method, and the other is plastic analysis in which collapse mechanism is assumed. In both analysis large deformation is considerd.

The following conclusions are obtained.

1) Theoretical results are checked with available published data. It is confirmed that this proposed method is fairly efficient one.

2) Since this proposed method is an analytical one that the complicated collapse strength of a pipe with out-of-roundness under combined loads can easily be estimated comparing with other numerical methods.

3) Analytical results indicate that there exist two different collapse modes for pipelines under combined bending and external pressure. One of them is circumferential flattening of pipe cross section (circumferential collapse) and the other is so-called Brazier's type of failure (bending collapse).

4) Analytical results show that both bending moment and axial tension considerably reduce the external pressure-bearing capacity.

\section{* 東京大学工学部}




\section{1 緒言}

石油，ガス等を輸送するための海底パイプラインの建 設は年々増加し, より深い海, より荒い海へ進出しつつ ある。現在計画されているもので, ノルウェーの海溝横 断パイプラインの水深は $350 \mathrm{~m}$ 以上であり, 地中海横 断パイプラインでは水深 $2,000 \mathrm{~m}$ を超える海域もある といわれる1。大水深に扣けるパイプラインの敷設時に は海水による高い外圧の外帴設法による大きな軸方向 曲げと軸力とからなる組合せ荷重が作用するため, 敷設 時の強度設計は極めて重要である。

Fig. 1 は現在最も多く用いられている敷設船による敷 設の例である。水深が大きい場合には Sagbend 部の曲 げ応力を減少させる目的で Tensioner によって引張力 を与える方法が用いられる。しかし，曲げと軸力との組 合せ荷重による軸方向歪が弾性域を超えることは避け難 い。DNV 規則 ${ }^{2)}$ では敷設後の軸方向残留歪の許容限界 值を $0.2 \%$ として拈り，敷設時にはこれを大きく超える 歪が生じていることになり, パイプライン敷設時の過酷 な状況を示唆している。

一方, 初期变形に対して API 規則 ${ }^{3)}$ では，（1）式で 与兄られる断面の初期偏平率を $1 \%$ 以内規定してい る。

$$
\frac{D_{\max }-D_{\min }}{D_{\max }+D_{\min }} \times 100
$$

ここで $D_{\max }, D_{\min }$ はそれぞれパイプの直径の最大 值, 最小值である。外圧が作用する場合には $1 \%$ 程度の 初期偏平においても崩壊強度の低下が無視できないとさ れている。

このようにパイプライン敷設時の崩壊強度は, 荷重の 組合せ, 材料特性, 断面寸法, 初期撓及等に支配され, かつ, 材料非線形と幾何学的非線形が混在するため, 厳 密な解析は極めて困難である。

パイプの強度に関する研究は古くから数多くなされて いるが，ここでは特に本研究と関連の深い研究の概要を 述べる。

1927年にパイプの純曲げに関する歷史的な論文が

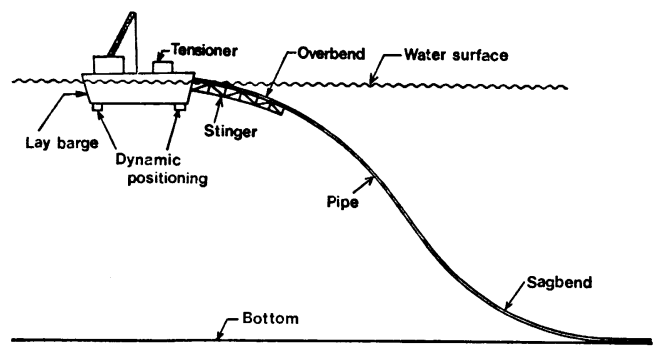

Fig.1 Pipeline laying operation (lay barge method)
Brazier4)によって発表された。Brazier は曲げによるパ イプ断面の偏平化 (Brazier effect) を考虑した弾性解 析を行い, 断面の偏平化によって曲げモーメントに極值 が存在することを明らかにするとともに，この限界モー メントの值とそのときの限界曲率を求めた（(33）式)。 後に Reissner ${ }^{5)}$ は Brazier の解析で運動学的関係式の 非線形項を無視したことによる不正確さを改良するとと もにより一般的な曲げ問題に抎張した。一方, 池田 ${ }^{6}$ は Brazier の解析を曲げと圧力との組合せ荷重を受ける問 題に払張して,よく知られている圧力と曲げモーメント との相関関係式を導いた（(34）式)。Timoshenko らは その著名な著書》の中で初期偏平を有するパイプに外圧 が作用する問題に対する精度の良い弾性解を導いた。 Gellin ${ }^{8)}$ は Brazier の曲げ問題を㧪張して，弾塑性大 撓みを考虑したモダンな数值解析法を提案した。

本研究のテーマである海底パイプラインの崩壊強度に 関する研究は，大水深海域への敷設計画と相俊って近年 特に諸外国において実験扩よび解析法の両面から精力的 に行われている。

Haagsma ら99は初期偏平を有するパイプに軸力と外 圧との組合せ荷重が作用する問題に対して前述の Timoshenko の弾性解と塑性解析法とを組合せた簡易式を提 案し，鋼製パイプを用いた実験結果と比較的良く一致す ることを示した。Winter ${ }^{10)}$ は同様な手法で,より簡易な 解析モデルを用いて，外圧，軸力，曲げ拉よび初期偏平 を考慮した簡易解析法を提案した。しかし，外圧と曲げ の組合せ荷重に対しては精度上問題があり, 再検討を要 するとしてその解析法を示していない。

Kyriakides ら ${ }^{11}$ は前述の Gellin の解析法を拡張し て，曲げと外圧との組合せ荷重を受けるパイプに対する 非線形数值解析法を開発し，アルミニウム合金製パイプ を用いた実駼結果と比較してほぽ一致した結 果を示し た。

このように, 軸力と外圧との組合せ荷重に対して初期 偏平を考慮した崩壊強度解析は比較的容易であるため, 解析的手法を用いた実用的な簡易解析法が提案されてお り，実際の設計に用いられている。しかし，曲げを含ん だ組合せ荷重に対しては，前述のように曲げによる断面 の偏平化と弾性域を超える軸方向歪の発生とによりその 崩壊挙動は極めて複雑になるため, 実用的な解析法が確 立されていない。

そこで，本研究では著者のうちの二人 ${ }^{12}$ が防撓板の压 縮強度沉ついて提案した弾性大撓及解析之大撓及を考慮 した塑性解析とを組合せた崩壊解析法を㧪張して, パイ プライン敷設時の崩壊強度を支配する主要因子と考兄ら れる曲げ，軸力および外圧からなる荷重の組合せと初期 撓みの影響を統一的に取り入れた実用的でかつ見通しの 
良い簡易解析法を開発し，既に発表されている実験結果 と比較検討する。

\section{2 解 析 法}

直径に比べて十分長いパイプを対象としているので, 変形は崩壊直前まで軸方向に一様であると仮定できる。 したがってここでは単位長さのパイプの崩壊強度を解析 する。

\section{1 弾性大撓み解析}

Fig. 2 に示すように, 平均半径 $R$, 肉厚 $t$, 径方向に 初期撓み $w_{0}(\theta)$ を有するパイプに，曲げモーメント $M$ と軸力 $T$ および外压 $p$ が作用し，軸方向の曲率が $\kappa$ であ るときの弾性大撓及解析を行ら。なお， Reddy ${ }^{13)}$ はパイ プの純曲げによる崩壊実験結果の考察から, 曲げ強度を 考える場合は曲げモーメントよりも曲率を用いた方が適 切であることを指摘した。したがってここでは軸方向の

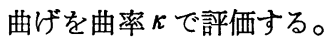

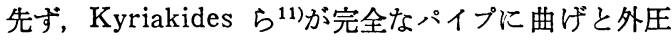
とが作用する問題の数值解析法に用いた基礎式に初期撓 みと軸力とを導入した定式化を行い，エネルギー原理に よって平衡方程式を導く。次に，断面変形々初期撓みを 仮定して Galerkin 法を用いて变位の未定係数に関する 方程式を導き，これを解いて変位を求める。

なお，本解析法では解析的な手法を主眼としているた め, 積分はすべて closed form で実行する。

\section{1 .1 運動学的関係式}

Fig. 3 亿示すように円周方向および径方向の変位をそ れぞれ $v, w$ とし, $\mathrm{Brush}^{14)}$ の表示に初期撓みを導入し た運動学的関係式を導く。

先ず次の仮定をおく。
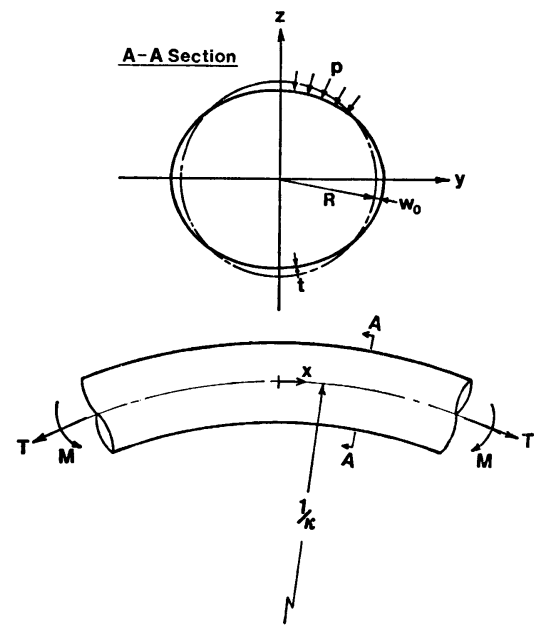

Fig. 2 Out-of-round pipe under combined bending, pressure and axial force

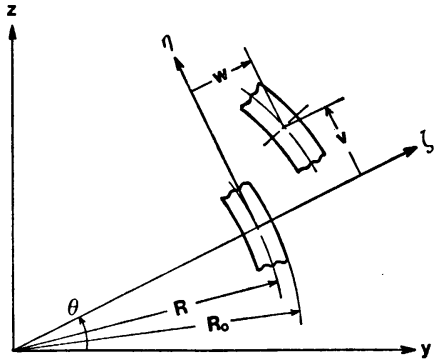

Fig. 3 Circumferential element before and after deformation

1）径方向に $w_{0}(\theta)$ の初期撓みを考える。

2）歪は微小である。

3）中程度 (肉厚の数倍) の変形を考觉る。

4）断面の変形は不伸長変形とする。

5）中立軸汪垂直な断面は変形後も垂直を保つ。

以上の仮定より周方向の歪 $\varepsilon_{\theta}$ は次のように表わされ る。

$$
\varepsilon_{\theta}=\varepsilon_{\theta}{ }^{0}+\zeta \kappa_{\theta}
$$

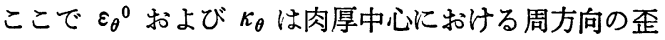
および周方向の曲率であり, 中程度の变形では次式で与 えられる。

$$
\left.\begin{array}{l}
\varepsilon_{\theta}{ }^{0}=\frac{v^{\prime}+w}{R}+\frac{1}{2}\left(\frac{v-w^{\prime}}{R}\right)^{2}-\frac{w_{0}\left(v-w^{\prime}\right)}{R^{2}} \\
\kappa_{\theta}=\frac{v^{\prime}-w^{\prime \prime}}{R^{2}}
\end{array}\right\}
$$

ここで ()$^{\prime}$ は $\theta$ に関する微分を表わす。

したがって，仮定 4）の周方向の不伸長条件は次式で 表わされる。

$$
\frac{v^{\prime}+w}{R}+\frac{1}{2}\left(\frac{v-w^{\prime}}{R}\right)^{2}-\frac{w_{0}^{\prime}\left(v-w^{\prime}\right)}{R^{2}}=0
$$

次に, パイプの軸方向の歪は肉厚内の変化を無視して 肉厚中心での值を用いる。軸力 $T$ による歪を $\varepsilon_{a}$ とする と軸方向の歪 $\varepsilon_{x}(\theta)$ は次式で与えられる。

$$
\varepsilon_{x}(\theta)=\boldsymbol{z}(\theta) \kappa+\varepsilon_{a}
$$

幾何学的関係上り

$$
\boldsymbol{z}(\theta)=\left(R+w_{0}+w\right) \sin \theta+v \cos \theta
$$

したがって

$$
\varepsilon_{x}(\theta)=\left\{\left(R+w_{0}+w\right) \sin \theta+v \cos \theta\right\} \kappa+\varepsilon_{a} \quad(7)
$$

2.1.2 構成方程式

平面応力状態を仮定すると応力-歪関係は

$$
\left.\begin{array}{l}
\sigma_{x}=\frac{E}{1-\nu^{2}}\left(\varepsilon_{x}+\nu \varepsilon_{\theta}\right) \\
\sigma_{\theta}=\frac{E}{1-\nu^{2}}\left(\varepsilon_{\theta}+\nu \varepsilon_{x}\right)
\end{array}\right\}
$$

ここで $\sigma_{x}, \sigma_{\theta}$ はそれぞれ軸方向および周方向の応力 であり，E，山はそれぞれヤング率拉よびポアソン比であ る。 
周方向の肉厚中心には(3)式の第 1 式の他に次式に示 す St. Venant の曲げ理論による歪が生ずる。

$$
\varepsilon_{\theta}{ }^{0}=-\nu \varepsilon_{x}
$$

(2)，（9）式を（8）式に代入して整理すると次の 構成方程式が得られる。

$$
\left.\begin{array}{l}
\sigma_{x}=E \varepsilon_{x}+\zeta \frac{E \nu}{1-\nu^{2}} \kappa_{\theta} \\
\sigma_{\theta}=\zeta \frac{E}{1-\nu^{2}} \kappa_{\theta}
\end{array}\right\}
$$

2.1 .3 全ポテンシャルエネルギー

パイプの歪エネルギーUは次のように表わされる。 $U=\frac{1}{2} \int_{V} \sigma_{i \jmath} \varepsilon_{i j} d V=\frac{1}{2} R \int_{0}^{2 \pi} \int_{-t / 2}^{t / 2}\left(\sigma_{x} \varepsilon_{x}+\sigma_{\theta} \varepsilon_{\theta}\right) d \zeta d \theta$

$$
=\frac{1}{2} R \int_{0}^{2 \pi}\left\{E t \varepsilon_{x^{2}}+\frac{E t^{3}}{12\left(1-\nu^{2}\right)} \kappa_{\theta}^{2}\right\} d \theta
$$

一方, 均一な静水压が变形状態でのパイプの外表面に 垂直に作用する場合, 外圧のポテンシャルエネルギー $\Omega$ は外圧とパイプの外表面が囲む面積の変化量との積で与 えられる。

Brush ${ }^{14)}$ の表示に初期撓みの影響を考虑すると，外圧 のポテンシャルエネルギーは次式で与えられる。

$$
\begin{aligned}
\Omega=p R_{0} \int_{0}^{2 \pi}[w+ & \frac{1}{2 R_{0}}\left\{v^{2}-v\left(w+w_{0}\right)^{\prime}\right. \\
& \left.\left.+v^{\prime}\left(w+w_{0}\right)+w^{2}+2 w w_{0}\right\}\right] d \theta
\end{aligned}
$$

ここで $R_{0}$ はパイプの平均外半径である。

したがって, 全ポテンシャルエネルギーПは次式で表 わされる。

$$
\Pi=\int_{0}^{2 \pi} F d \theta
$$

$$
\begin{aligned}
& \text { ここで } \\
& \begin{aligned}
F= & \frac{1}{2} R\left\{E t \varepsilon_{x^{2}}+\frac{E t^{3}}{12\left(1-\nu^{2}\right)} \kappa_{\theta}{ }^{2}\right\} \\
+ & +p R_{o}\left[w+\frac{1}{2 R_{o}}\left\{v^{2}-v\left(w+w_{0}\right)^{\prime}+v^{\prime}\left(w+w_{0}\right)\right.\right. \\
& \left.\left.\quad+w^{2}+2 w w_{0}\right\}\right]
\end{aligned}
\end{aligned}
$$

\subsection{4 平衡方程式}

エネルギー原理より, 平衡の条件は（13）式の被積分 関数 $F$ が次の Euler-Lagrange の方程式を満たすことで 西る。

$$
\left.\begin{array}{c}
\frac{\partial F}{\partial v}-\frac{d}{d \theta} \frac{\partial F}{\partial v^{\prime}}=0 \\
\frac{\partial F}{\partial w}-\frac{d}{d \theta} \frac{\partial F}{\partial w^{\prime}}+\frac{d^{2}}{d \theta^{2}} \frac{\partial F}{\partial w^{\prime \prime}}=0
\end{array}\right\}
$$

（14）式のF゙（15）式に代入して整理すると，周方 向および径方向の平衡方程式はそれぞれ次式のよらに得 られる。

$$
\left.\begin{array}{c}
E R t \kappa^{2}\left\{\left(R+w_{0}+w\right) \sin \theta+v \cos \theta+\frac{\varepsilon_{a}}{\kappa}\right\} \cos \theta \\
-\frac{E t^{3}}{12\left(1-\nu^{2}\right) R^{3}}\left(v-w^{\prime}\right)^{\prime \prime}+p\left(v-w_{0}^{\prime}-w^{\prime}\right)=0 \\
E R t \kappa^{2}\left\{\left(R+w_{0}+w\right) \sin \theta+v \cos \theta+\frac{\varepsilon_{a}}{\kappa}\right\} \sin \theta \\
-\frac{E t^{3}}{12\left(1-\nu^{2}\right) R^{3}}\left(v-w^{\prime}\right)^{\prime \prime \prime}+p\left(R_{0}+v^{\prime}+w_{0}+w\right)=0
\end{array}\right\}
$$

\subsection{5 変位関数}

パイプの断面变形を 2 軸対称と仮定して初期撓みを考 慮した变位関数を定める。変位 $v, w$ および初期撓及 $w_{0}$ を次のように仮定する。

$$
\begin{aligned}
& w=R \sum_{j=0}^{N} a_{j} \cos 2 j \theta, \quad v=R \sum_{j=1}^{N} b_{j} \sin 2 j \theta \\
& w_{0}=R W_{0} \cos 2 \theta
\end{aligned}
$$

不伸長条件の計算を容易にするために次のようにお <。

$$
\frac{v^{\prime}+w}{R}=\sum_{j=0}^{N} c_{j} \cos 2 j \theta, \frac{v-w^{\prime}}{R}=\sum_{j=1}^{N} d_{j} \sin 2 j \theta
$$

(17)，（19）式より各係数間には次の関係がある。

$$
a_{j}=\frac{2 j d_{j}-c_{j}}{4 j^{2}-1}, \quad b_{j}=\frac{2 j c_{j}-d_{j}}{4 j^{2}-1}
$$

不伸長条件を表わす（4）式に（18)，（19）式を代入 して整理すると， $c$ 子とd,との関係は次式で与えられ る。

$$
\begin{aligned}
c_{0}= & -\frac{1}{4}\left(\sum_{j=1}^{N} d_{j}^{2}\right)-d_{1} W_{0} \\
c_{i}= & -\frac{1}{2}\left(\sum_{j=1}^{N-i} d_{j} d_{j+i}\right) \\
& +\frac{1}{4}\left(\sum_{j=1}^{i-1} d_{j} d_{i-j}\right)+\left(d_{i-1}-d_{i+1}\right) W_{0} \\
c_{N}= & \frac{1}{4}\left(\sum_{j=1}^{N-1} d_{j} d_{N-j}\right)+d_{N-1} W_{0}
\end{aligned}
$$

\section{$N+1$ 項以降は無視する。}

Gellin ${ }^{8)}$ はパイプの弾性曲げ問題に対する数值解析結 果から, 变位関数の項数 $N$ による精度の収束は極めて早 く，N=4 で十分な精度が得られ， $N=2$ 飞执いても $N$ $=4$ に対する諸量（限界モーメントとそのときの曲率, 応力および撓み）の誤差は $1 \%$ 以内であることを確認し た。

本解析では解析的手法を用いるため項数を多くとると 積分等の手数が増大する, したがって，Gellinの結果を 参考にして $N=2$ とする。

(17)～(21）式より撓みは次式のように $d_{1}$ と $d_{2}$ と の 2 個の未知数で表わされる。

$$
\begin{aligned}
w=R\{- & \frac{1}{4}\left(d_{1}^{2}+d_{2}^{2}\right)-W_{0} d_{1} \\
& +\frac{1}{3}\left(2 d_{1}+\frac{1}{2} d_{1} d_{2}+W_{0} d_{2}\right) \cos 2 \theta
\end{aligned}
$$




$$
\begin{array}{r}
\left.+\frac{1}{15}\left(-\frac{1}{4} d_{1}{ }^{2}+4 d_{2}-W_{0} d_{1}\right) \cos 4 \theta\right\} \\
v=R\left\{-\frac{1}{3}\left(d_{1} d_{2}+d_{1}+2 W_{0} d_{2}\right) \sin 2 \theta\right. \\
\left.+\frac{1}{15}\left(d_{1}{ }^{2}-d_{2}+4 W_{0} d_{1}\right) \sin 4 \theta\right\}
\end{array}
$$

\section{1 .6 変分原理}

（18）式の初期撓みと（22）式の変位関数を用いて （16）式の平衡方程式を Galerkin 法で解く。

すなわち，（16）式の第 1 式および第 2 式の左辺をそ れぞれ $\phi_{t}$ および $\phi_{r}$ とおくと Galerkin 法による変分 方程式は次式で表わされる。

$$
\int_{0}^{2 \pi}\left(\phi_{t} \delta v+\phi_{r} \delta w\right) d \theta=0
$$

積分を実行して整理すると次の形の方程式を得る。

$$
\sum_{i=1}^{2} f_{i} \delta d_{i}=0
$$

これより次の 2 元連立方程式が得られる。

$$
f_{i}=0 \quad(i=1,2)
$$

(24) 式は具体的には $d_{1}$ と $d_{2}$ に関する 3 次の連立方 程式となる。この方程式の係数は紙面の都合により今回 は示すことができないが，係数の中には軸力による歪 $\varepsilon_{a}$ が含まれていない。したがって，軸力は断面の弾性 変形には影響を及ぼさない。

（24）式の解は, Cardano 法により電子計算機を用い て, 繰返し計算を行って求めた。後述の解析例では数回 の繰返しにより速やかに収束した。

\section{1 .7 曲げモーメント}

曲率が $\kappa$ で軸力による歪が $\varepsilon_{a}$ である場合の，塑性化 を考慮した軸方向応力の肉厚中心における值 $\sigma_{x}^{0}$ の分布 は容易に定められる (Fig. 4)。

この応力分布と弾性解析より求めた断面の変形形状を 用いて，次式により曲げモーメントを求めることができ る。

$$
M=R t \int_{0}^{2 \pi} \sigma_{x}^{0} z d \theta
$$

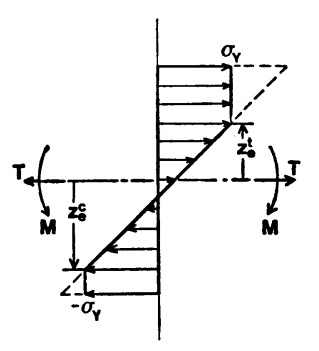

Longitudinal stress distribution

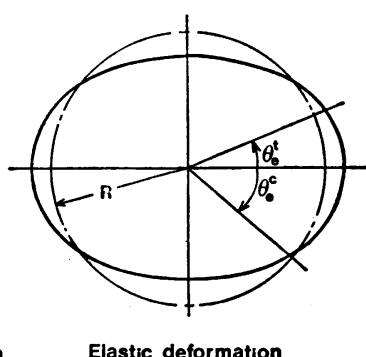

Elastic deformation
Fig. 4 Longitudinal stress distribution due to bending and axial force

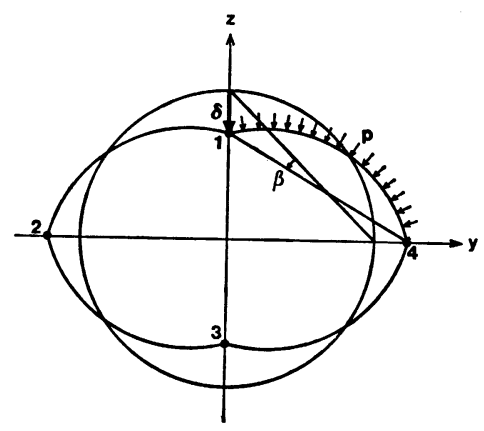

Fig. 5 Circumferential collapse mode assumed in plastic analysis

（25）式の積分は（6）式の $z$ を用いて closed form で実行する。

\section{2 塑 性 解 析}

曲率が $\kappa$, 軸歪が $\varepsilon_{a}$ で外圧 $p か ゙$ 作用する場合の変形 を考慮した塑性解析を行う。

崩壊モードを Fig. 5 に示す 4 点塑性ヒンジモードと 仮定する。

\subsection{1 内部仕事}

変形状態における各ヒンジ点の塑性モーメントを, 加 藤ら ${ }^{15)}$ が板の塑性解析に用いた手法を参考にして, 次の 仮定に基づいて求める。

1）大変形を考劣る。

2）中立軸に垂直な断面は変形後も垂直を保つ。

3）材料は Mises の降伏条件に従ら完全剛塑性体と する。

4）曲げと軸力とによる軸方向の応力は肉厚中心で評 価し，その值を $\sigma_{x}{ }^{0}$ とする。この $\sigma_{x}{ }^{0}$ は周方向応 力の影響を受けず, $\sigma_{Y}$ で降伏する。

以上の仮定に基づいて, Fig. 5 に示すようにパイプの 外表面に垂直に外圧 $p$ が作用し, 軸方向応力 $\sigma_{x}{ }^{0}$ が存在 するときのヒンジ点 $i$ での塑性モーメント $m_{\theta}(i)$ は次 式のように求められる。

$$
\begin{aligned}
& m_{\theta}(i)=2 m_{\mathrm{p}}\left\{1-\left(\frac{\sigma_{x}^{0}(i)}{\sigma_{Y}}\right)^{2}-\left(\frac{p R_{o}}{t \sigma_{Y}}\right)^{2}-\left(\frac{p R_{o}}{t \sigma_{Y}}\right)\right. \\
&\left.\times\left(\frac{\sigma_{x}^{0}(i)}{\sigma_{Y}}\right)\right\} / \sqrt{4-3\left(\frac{\sigma_{x}^{0}(i)}{\sigma_{Y}}\right)^{2}}
\end{aligned}
$$

ここで

$$
\begin{aligned}
& m_{p}=t^{2} \sigma_{Y} / 4 \\
& \sigma_{x}^{0}(\boldsymbol{i})=E \kappa z(\boldsymbol{i})+E \varepsilon_{a}
\end{aligned}
$$

また，肉厚中心における周方向応力 $\sigma_{\theta}{ }^{0}$ は Fig. 5 の $1 / 4$ 円の力の釣合より, 次式のように変形量 $\beta$ にらず 一定である。

$$
\sigma_{\theta}{ }^{0}=-p R_{o} / t
$$


各ヒンジに护ける回転角はいずれも $2 \beta$ であるので内 部仕事 $V$ は

$$
\begin{aligned}
& V=2 \beta M_{\theta} \\
& \text { ここで } \quad M_{\theta}=\sum_{i=1}^{4} m_{\theta}(i)
\end{aligned}
$$

内部仕事の变分 $\delta V$ は $m_{\theta}(i)$ の中の $\sigma_{x}{ }^{0}(i)$ が变形 量 $\beta$ の関数であるから

$$
\begin{aligned}
\delta V & =2\left(\frac{\partial M_{\theta}}{\partial \beta} \beta+M_{\theta}\right) \delta \beta \\
& =2\left\{\sum_{i=1}^{4}\left(\frac{\partial m_{\theta}(i)}{\partial \sigma_{x}^{0}(i)} \frac{\partial \sigma_{x}^{0}(i)}{\partial \beta} \beta+m_{\theta}(i)\right)\right\} \delta \beta
\end{aligned}
$$

ここで

$$
\begin{aligned}
\frac{\partial m_{\theta}(i)}{\partial \sigma_{x}{ }^{0}(i)}=2 m_{p} & \left\{-5\left(\frac{\sigma_{x}^{0}(i)}{\sigma_{Y}}\right)+3\left(\frac{\sigma_{x}^{0}(i)}{\sigma_{Y}}\right)^{3}-4\left(\frac{p R_{0}}{t \sigma_{Y}}\right)\right. \\
& \left.-3\left(\frac{\sigma_{x}^{0}(i)}{\sigma_{Y}}\right)\left(\frac{p R_{o}}{t \sigma_{Y}}\right)^{2}\right\} / \\
& {\left[\sigma_{Y}\left\{4-3\left(\frac{\sigma_{x}^{0}(i)}{\sigma_{Y}}\right)^{2}\right\}^{3 / 2}\right] }
\end{aligned}
$$

ただし

$$
\left|\sigma_{x}^{0}(i)\right|=\sigma_{Y} \text { のとき } \frac{\partial \sigma_{x}^{0}(i)}{\partial \beta}=0
$$

\subsection{2 外部仕事}

外部仕事は2.1.3 項と同様に, 外圧とパイプ外表面が 囲む断面積の変化量との積で与えられる。

Fig. 5 において，ヒンジ点以外の円弧は剛体であるか ら 4 個の部分円の面積は不変である。変形状態が $\beta$ であ るときに, 各ヒンジ点の外表面を結んだ四辺形の面積 $A$ は

$$
A=2 R_{o}^{2}\left(1-2 \sin ^{2} \beta\right)
$$

である。

$A$ の変分 $\delta A$ は

$$
\delta A=-4 R_{0}^{2} \sin 2 \beta \delta \beta
$$

である。したがって外部仕事の変分 $\delta W$ は次式で与兄 られる。

$$
\delta W=p \delta A=-4 p R_{o}^{2} \sin 2 \beta \delta \beta
$$

\subsection{3 仮想仕事の原理}

仮想仕事の原理より

$$
\delta V+\delta W=0
$$

（30）式に（28），(29）式を代入して変形すると

$$
\begin{aligned}
\beta= & \frac{1}{2} \arcsin \left[\frac { 1 } { 2 p R _ { o } ^ { 2 } } \left\{\sum _ { i = 1 } ^ { 4 } \left(\frac{\partial m_{\theta}(i)}{\partial \sigma_{x}{ }^{0}(i)} \frac{\partial \sigma_{x}^{0}(i)}{\partial \beta} \beta\right.\right.\right. \\
& \left.\left.\left.+m_{\theta}(i)\right)\right\}\right]
\end{aligned}
$$

（31）式を用いて絽返し計算により $\beta$ を求める。 ヒンジ点 1 の垂直変位 $\delta$ は次式より求められる。

$$
\delta=R\{1-(\cos \beta-\sin \beta)\}
$$

パイプの崩壊強度は, 弾性解による $z$ 軸上の垂直変位 と塑性解の $\delta$ とが等しくなる条件によって求められる。
ここでは電子計算機を用いて数值的に両者の交点を求め た。

\section{3 解 析 結 果}

本解析法の適用性を検証する目的で, Kyriakides ら がアルミニウム合金（Al-6061-T 6) 製パイプを用いて 行った実験結果と数值解析法による計算結果, および, Haagsma らが初期偏平を有する鋼製 (ASTM A 106 GR. B) パイプを用いて, 外圧, 曲げと外圧, 軸力と外 圧の各荷重に対して行った実験結果との比較検討を行 ら。

両者が実験に用いたパイプの材料特性と断面寸法とを Table 1 に示す。なお，Kyriakides らが解析に用いた 材料の応力-歪関係式, および, Haasgma らによる材料 実験結果より, 両材料の丕硬化は無視できるものと推察

\begin{tabular}{|c|c|c|c|c|c|c|}
\hline Material & Gredo & 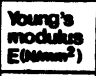 & $\begin{array}{l}\text { Poisson's } \\
\text { ratio } \\
\nu\end{array}$ & 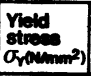 & $\begin{array}{l}\text { Mean } \\
\text { diameter } \\
\text { D(mm) }\end{array}$ & $\begin{array}{c}\text { Thicknoses } \\
\text { t(mm) }\end{array}$ \\
\hline AI-6061 & To & 68600 & 0.34 & 295 & 31.75 & 089 \\
\hline ASTM A106 & B & 205800 & 0.3 & 320 & 98.0 & 4.0 \\
\hline
\end{tabular}
できる。

また, 本解析で $D / t$ を变えた計算では, 肉厚 $t$ を一 定（Table 1 の值）として直径Dを変化させて行った。

初期撓みを仮定した（18）式より，本解析での $W_{0}$ は （1）式で示した初期偏平率を表わしている。したがっ て以下では, 初期偏平率を表わすパラメータにこの $W_{0}$ を用いる。

\section{1 弾性解析の検証}

本解析で用いている弾性解析の精度を検証するため に, 曲げと外圧との組合せ荷重を受けるパイプの弾性解 析を行い，他の研究者による解析結果と比較する。

Fig. 6 は Table 1 に示した Al-6061 製パイプのデー タを用いて本解析法の弾性解析により求めた曲げと外圧

Table 1 Characteristics of pipes tested ${ }^{\text {(11) }}$

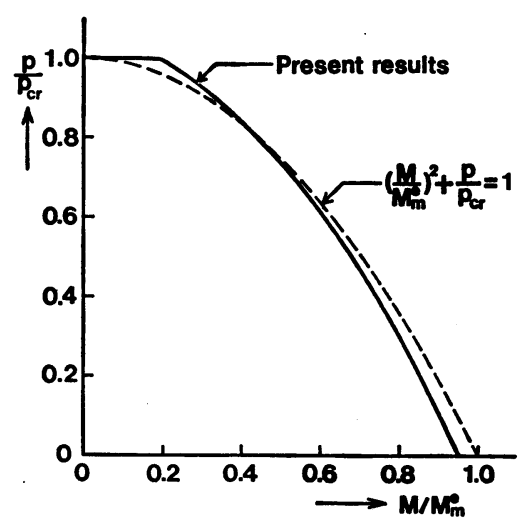

Fig. 6 Moment-pressure interaction diagram in elastic state 
との相関曲線である。

四の綐軸の圧力は座屈圧力 $p_{c r}\left(=E t^{3} / 4\left(1-\nu^{2}\right) R^{2} R_{0}\right)$ で，横軸の曲げモーメントは純曲げに対する Brazierの 限界モーメント $M_{m}{ }^{e}$ ((33) 式)でそれぞれ無次元化し てある。

Brazier が求めた限界モーメント $M_{m}^{e}$ 之限界曲率 $\kappa_{m}^{e}$ および断面の最大变位 $\delta_{m}^{e}$ は次式で与えられる。 $M_{m} e=\frac{2 \sqrt{2}}{9} \frac{E \pi R t^{2}}{\sqrt{1-\nu^{2}}}, \quad \kappa_{m}{ }^{e}=\frac{\sqrt{2}}{3} \frac{t}{R^{2} \sqrt{1-\nu^{2}}}, \quad \delta_{m}^{e}=\frac{2}{9} R$

また, 同図中の破線は池田による次の相関関係式であ る。

$$
\left(\frac{M}{M_{m} e}\right)^{2}+\frac{p}{p_{c r}}=1
$$

$p=0$ に执いて両曲線のモーメントの值が違っている。 この違いは Brazier の解の精度が悪いためである。ま た，本解析結果で， $p / p_{c r}=1$ においても曲げモーメント を支え得るのは，本解析法では座屈後強度を考慮してい ることによるものと思われる。

本解析法による結果で, $p=0$ に护ける限界モーメン トと限界曲率はそれぞれ $M / M_{m}^{e}=0.950, \kappa / \kappa_{m}^{e}=$ 0.957 であり, Kyriakides らが (17) 式の変位関数で 項数を $N=4$ として解析した結果と全く一致している。 また，外圧が作用する場合には，数值が示されていない ために定量的な比較はできないが，グラフ上で全く一致 している。

Kyriakides らはこの項数 $N$ による影響を数值解析に より検討した結果, 曲げと外圧との組 合せ荷重に対し て, 弾性解析のみでなく, 弾塑性解析においてる $N=4$

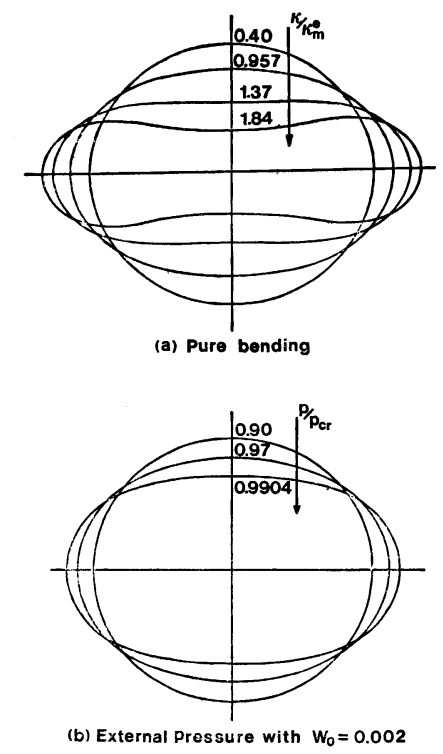

Fig. 7 Elastic deformation sequences
で十分な精度が得られることを確認している。

以上の結果より, 曲げと外圧との組合せ荷 重に対し て， $N=2$ を用いている本解析法の弾性解は十分な精度 が得られていることが確認できた。

Fig. 7 (a ) は純曲げの場合の弾性解析による断面の変 形過程を示したものである。眓中の曲率は（33）式の Brazier の限界曲率で無次元化してある。

$\kappa / \kappa_{m}{ }^{e}=0.40$ は (25) 式で塑性化を考慮した曲げモー メントが極值に達した状態であり, $\kappa / \kappa_{m}^{e}=0.957$ は純 弾性と仮定した場合に曲げモーメントが極值に達した状 態である。

Fig. 7 (b ) は微小な初期偏平 $W_{0}=0.002$ を与えて外 圧を加えた場合の断面变形である。曲げによる変形と, 外圧による変形とは良く似ている。

\section{2 崩壊解析結果}

Fig. 8 は ASTM A 106 製パイプの崩壊圧力に及ぼす 初期偏平率の影響を $D / t=24,50$ について示したもの である。この図では縦軸の圧力を理論的な降伏圧力 $p_{Y}$ $\left(=t \sigma_{Y} / R_{0}\right)$ で無次元化してある。

本解析結果は Haagsma らの解析結果と良く一致して おり，実験值より $10 \%$ 程度高い崩壊圧力を与えてい る。また, 初期偏平率の影響は $D / t$ が小さい程大きい ことを示して扣り，API 規則の許容初期偏平率である $W_{0}=0.01$ に打いて, $D / t=24$ のパイプでは崩壊圧力が 約 $40 \%$ 減少している。

Fig. 9 は Al-6061 製パイプの曲げと外圧との組合せ 荷重に対する崩壊強度を Kyriakides らの実験結果扰よ び解析結果と比較したものである。この図では縦軸の圧 力は座屈圧力で無次元化し, 横軸の曲率は真円の状態 で, 曲げによる軸方向の最大応力が降伏応力に達すると きの曲率 $\kappa_{Y}\left(=\sigma_{Y} / E R:\right.$ 降伏曲率と呼ぶ）で無次元化 してある。

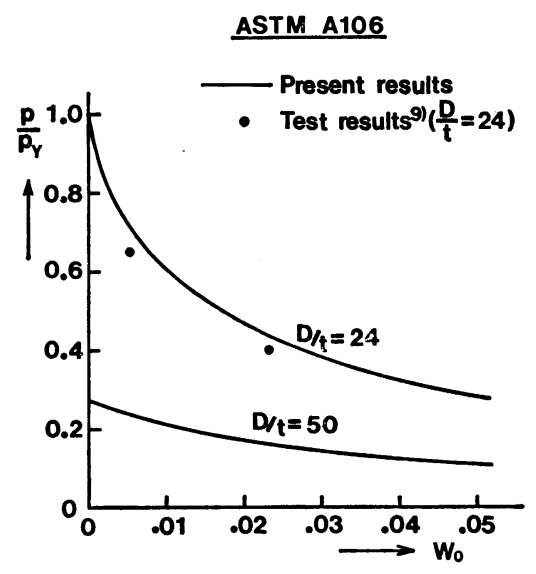

Fig. 8 Influence of out-of-roundness for steel pipes 
Al-6061 $D / t=34.71$
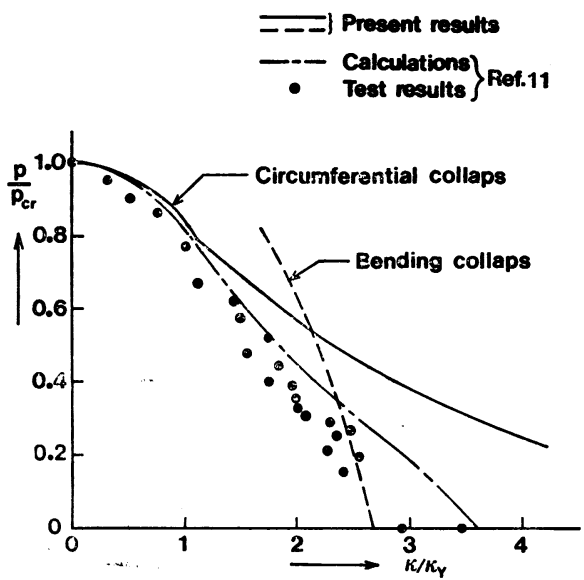

Fig. 9 Curvature-pressure interaction for aluminum pipes

本解析法による結果の実線は2.2 節の塑性解析で仮定 した 4 点ヒンジモードによる崩壊 (断面崩壊)を示す。 一方, 破線は (25) 式で応力の塑性化と断面の弾性変形 を考慮した曲げモーメントの值が限界となる（曲げ崩 壊）曲率を示している。したがって，実線と破線との交 点を超える外圧では断面崩壊モードで崩塄し, それ以下 の外圧では曲げ崩壊モードで崩壊する。この 2 つの崩壊 モードの存在は Haagsma ${ }^{16)}$ が実験により明らかにして いる。

曲げと外匠との荷重順序の影響については, 実験結果 に差が無かった ${ }^{11)}$ とるものや，曲率一定で外圧を增加 させた方が高い崩壊圧力が得られたが，更に実験による 検証を要する ${ }^{10)}$ とするものがあり, 現在のところ定説は ない。

本解析法では断面崩壊モードに対しては荷重順序にか かわらず同じ值が得られた。ところが，曲率一定で外圧 を増加する方法では曲げ崩壊モードが得られないため, 曲げと外圧との組合せ荷重の解析はすべて外圧一定で曲 率を増加させる方法で計算を行った。

Fig. 9 において $\kappa / \kappa_{Y}=1.1$ 付近で断面崩壊曲線にナ ックル点が現われている。これは Fig. 4 に示した上下 のヒンジの軸方向応力が降伏応力に達したためであり, $\kappa / \kappa_{Y}$ が 1 を超えているのは, 断面の偏平化によりこの 点の曲げ応力が緩和されているためである。

本解析結果と実験結果とを比較すると, 崩壊モードが 変る付近で実験点との差が最も大きくなっているが，全 体的には簡易解析法として十分適用できるるのと思われ る。

Fig. 10 は $p / p_{c r}=0.285$ における曲げモーメントと曲 率の関係を Kyriakides らの実験値および計算値と比較
$A l-6061 D / t=34.71$

$P / P_{t r}=0.285$

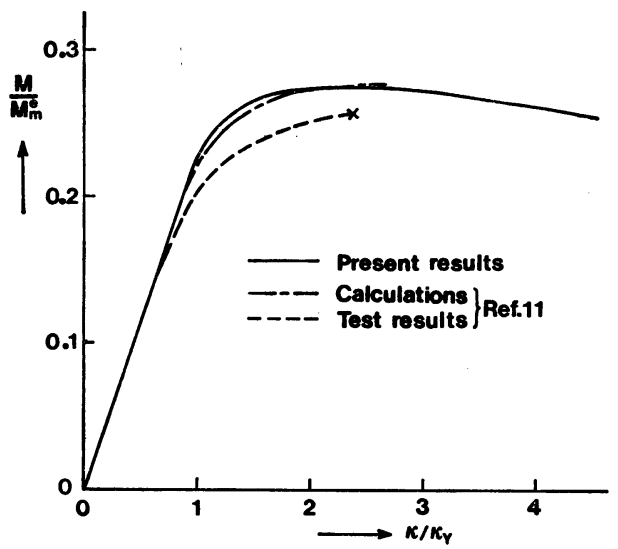

Fig. 10 Moment-curvature relation of aluminum pipe

したものである。実験では曲げモーメントを負荷して曲 率を計測しているため, 限界モーメント以降は示されて いない。また, Kyriakides らの計算は非線形数值解析 法であり，曲率増分に対してモーメントが僅かに減少し た時点で崩壊とみなし, 計算を中止しているため, 限界 モーメント以降の值は得られていない。

本解析法の結果によると, 限界モーメント以降曲率の 増加と共にモーメントは緩やかに減少している。したが って, スティンガー, ポンツーン等により曲げモーメン トを僅かに支持して曲率をコントロールすることによ り, 限界モーメント以降も広範囲な曲率にわたって安定 が保てることを示している。

Fig. 11 は Al-6061 製パイプで $D / t$ を変化させた場 合の曲げと外圧とによる崩壊解析結果である。 $D / t=15$ では降伏圧力が $0.857 p_{c r}$ であるので, 最大圧力がこの 值で規定されている。同図では $D / t$ が増加すると低い

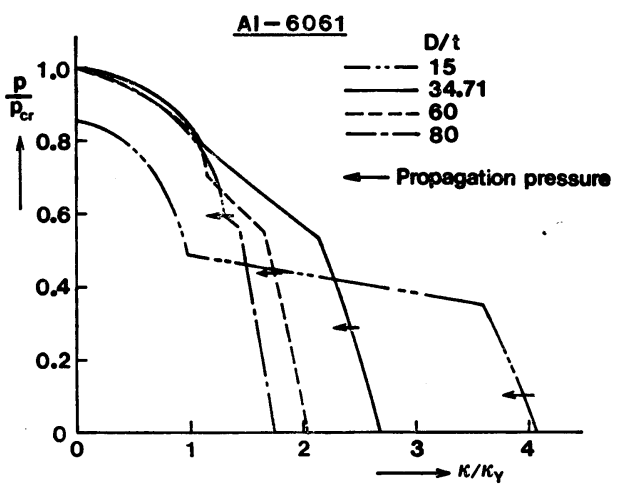

Fig. 11 Curvature-pressure interaction for various kinds of $D / t$ 
曲率比で曲げ崩壊が生ずることを示している。

Table 1 より, この材料の降伏麥は約 $0.4 \%$ である ので, 軸方向の残留歪が DNV 規則の許容值である $0.2 \%$ 残留すると仮定すると，敷設時には約 $0.6 \%$ の 卒が生じていることになる。これは $\kappa / \kappa_{Y}=1.5$ に相当 し， $D / t=80$ のパイプでは限界曲率に近い状態であるこ とを示している。

図中の矢印で示す圧力は各 $D / t$ に対する伝播圧力 (Propagation pressure $: p_{p}$ ) であり，DNV 規則に示 されている次式から計算した值である。

$$
p_{p}=1.15 \pi \sigma_{Y}\left(\frac{t}{D}\right)^{2}
$$

この伝播圧力は何らかの原因で局部的な崩壊が生じ, かつ，この圧力以上の外圧が作用している場合には外圧 のみで軸方向に座屈が伝播することを示す圧力である。 この現象は伝播座屈 (Propagating buckling) と呼ば れ，10 年程前に海底パイプラインの 敷設時に発生した Sagbend 部の局部座屈が, 敷設完了部に伝播し, 広範 囲な崩壊に至ったことから注目された現象である ${ }^{17) 。 ~}$

Fig. 12〜16 は ASTM A 106 製パイプの崩壊強度を 解析した結果である。

先ず, Fig. 12 は $D / t=24$ の場合の曲げと外圧との組 合せ荷重に対する崩壊強度を初期偏平率をパラメータと して表わしたものである。なお，綎軸の圧力は降伏圧力 で無次元化してある。図中の黒丸は $W_{0}=0$ の場合の実 験值である。実験点は少ないが本解析結果とほぼ一致し ている。

解析結果の $W_{0}=0$ に対する断面崩壊曲線に注目する と, 曲率が降伏曲率に近づくにつれて急激に崩壊圧力が 低下している。降伏曲率程度で強度が約 $40 \%$ 減少し, その後は緩やかな減少を示している。

初期偏平がある場合には全体として断面崩壊曲線は下 がっているが， $W_{0}=0$ の場合と同様な傾向を示してい る。しかし，限界曲率に及ぼす初期偏平の影響は小さ

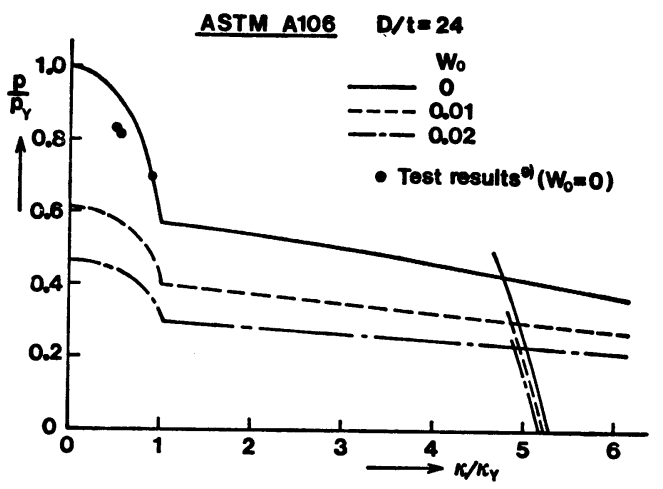

Fig. 12 Curvature-pressure interaction of steel pipes for various values of $W_{0}$

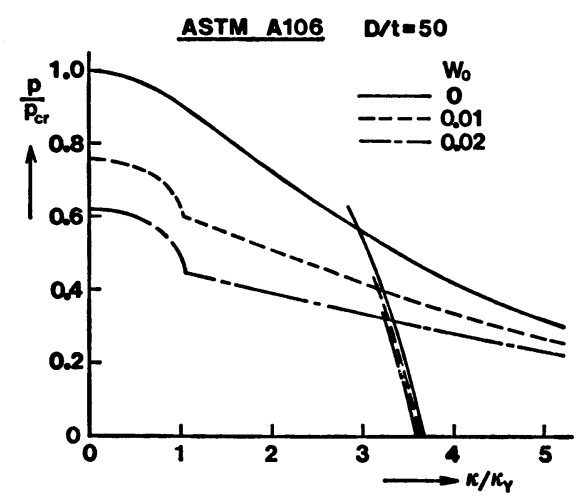

Fig. 13 Influence of $W_{0}$ for $D / t=50$

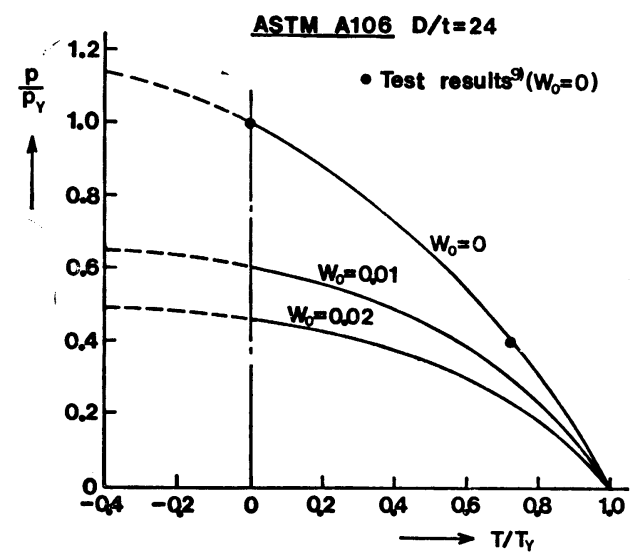

Fig. 14 Axial force-pressure interaction

く,かつ,ここには示していないが，限界モーメントの 值もほとんど初期偏平率に影響されないことが分かっ た。

Fig. 13 は $D / t=50$ について同様の計算を行った結果 である。この図では綎軸の圧力は座屈圧力で無次元化し てある。 $W_{0}=0$ の場合には $\kappa / \kappa_{Y} \leqq 1$ の領域で前図のよ らな急激な変化は見られない。

Fig. 14 は軸力と外仕との組合せ荷重に対する崩壊強 度を初期偏平率をパラメータとして表わしたものであ る。横軸の軸力は降伏軸力 $T_{Y}\left(=2 \pi R t \sigma_{Y}\right)$ で無次元化 してある。

軸力が引張力の場合は崩壊圧力を著しく低下させ, 逆 に圧縮力の場合は増加させる。しかし，海底パイプライ ンにおいては積極的に圧縮力を加えることはほとんどな w。

Fig. 15 は $D / t=24$ の場合の曲げ, 軸力および外圧の 組合せ荷重に対する崩壊強度を軸丕をパラメータとして 表わしたものである。軸力が作用する場合には Fig. 5 に示した上下のヒンジの軸方向応力が降伏応力に達する 曲率が異なるため, 断面崩壊曲線の 2 個所にナックル点 


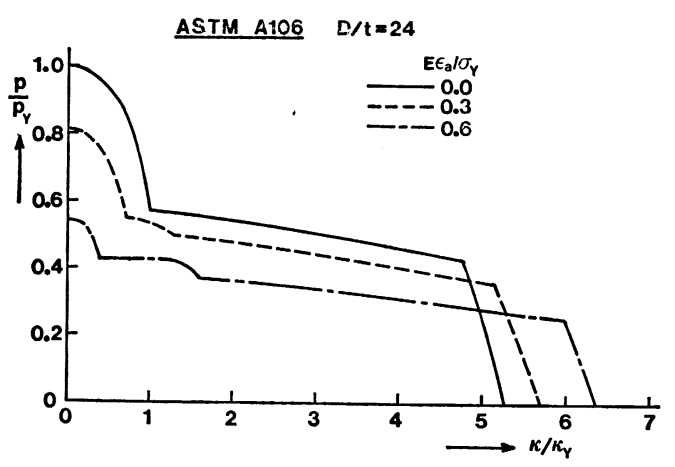

Fig. 15 Curvature-pressure interaction for various values of $E \varepsilon_{a} / \sigma_{Y}$

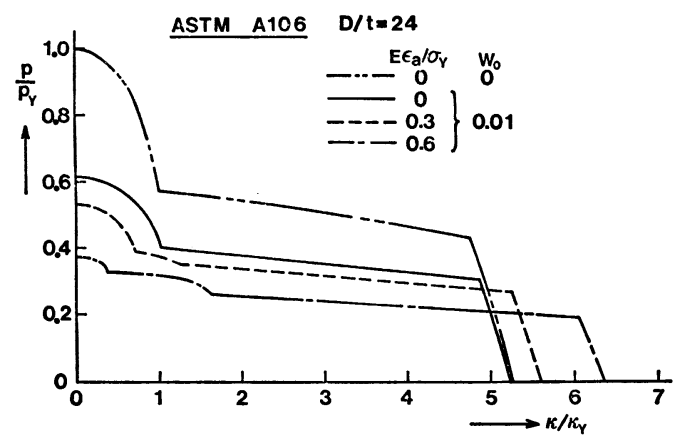

Fig. 16 Influence of $E \varepsilon_{a} / \sigma_{Y}$ and $W_{0}$

が現われている。この 2 点間の間隔は軸歪が高い程 広 い。

一方，曲げモーメントが限界值に達する限界曲率は軸 歪が高い程大きくなる。また，ここには示していない が，限界モーメントの值はほとんど軸歪の影響を受けな W。

Fig. 16 は前図の計算に API 規則の許容初期偏平率で ある $W_{0}=0.01$ を付加した場合の計算結果である。こ の図より初期偏平率と軸方向の残留歪とが各規則の許容 量程度であっても，それらの組合せによって崩壊強度が 著しく低下することが分かる。

\section{4 結言}

本論文では弾性大撓み解析と塑性大撓み解析とを組合 せて, 組合せ荷重を受けるパイプの崩壊強度を解析する 方法を提案した。この方法は解析的な手法を用いている ため，崩壊強度に及ぼす諸因子の影響が定量的かつ定性 的に推定できる。したがって，非線形数値解析法に比へ て見通しが良く，かつ計算が容易であるため，実踏の設 計に適用しやすい。

本解析法による解析結果と実験結果との比較により, 以下の結論が得られた。
1）実験結果との比較により，本解析法は海底パイブ ライン敷設時の崩壊強度設計に十分適用できると思われ る。特に本解析法により, 曲げと他の因子との複雑な相 関関係を定量的に設計に取り込むことができる。

2）海底パイプラインの敷設時の崩壊挙動は, 作用す る荷重の組合せ, 初期撓み, 材料特性扣よび断面寸法等 により複雑に変化する。また，これら諸因子はその崩壊 強度に大さな影響を及ぼす。

3）曲げと外圧との組合せ荷重が作用する場合には, 断面崩壊モードと曲げ崩壊モードの 2 種類の崩壊モード が存在する。

4）初期撓みにより断面崩壊モードによる崩壊強度は 低下するが，曲げ崩壊モードによる崩壊強度はほとんど 影響されない。

5）本解析法をマイクロコンピュータに組み込むこと により，設計四表を参照する程度の手数で容易にパイプ の崩壊強度が推定できる。また, 崩壊モードが明確に得 られるために見通しの良い設計ができる。

今後より広範囲な実験結果との比較により, 更に本解 析法の信頼性を検討するとともに，ライザ管等の類似の 構造物の崩壊強度解析への適用性も検討する。

最後に本論文の数值計算にあたっては, 東京大学大型 計算機センターの M $280 \mathrm{H}$, および東京大学船舶工学科 材料研究室のマイクロコンピュータ CS-3 を使用させて 戴きました。

\section{参 考 文 献}

1) B.K. Jinsi: Collapse and buckling-strength considerations are pinpointed for offshore pipeline design, Oil \& Gas Journal, May 3 (1982), pp. 217 227 .

2) Det Norske Veritas: Rules for the design, construction and inspection of submarine pipelines and risers (1976).

3) American Petroleum Institute: Specifications for line pipe, high-test line pipe, API Spec. 5 L, 5 LX, March (1982).

4) L. G. Brazier: On the flexure of thin cylindrical shells and other "thin" sections, Proc. R. Soc. Series A, Vol.116 (1927), pp. 104 114.

5) E. Reissner: On finite pure bending of cylindrical tubes, Österr. Ing. Arch., Vol. 15 (1961), pp. 165〜172.

6）池田：内圧をたは外圧を受ける薄肉円筒の曲げ, 日本航空学会誌, 第 7 巻, 第 68 号 (昭和 15 年 12 月), pp. $499 \sim 510$.

7) S. P. Timoshenko and J. M. Gere: Theory of elastic stability, 2 nd ed., McGraw-Hill(1961).

8) S.Gellin: The plastic buckling of long cylindrical shells under pure bending, Int. J. Solids Structures, Vol. 16 (1979), pp. 397 
407.

9) S. C. Haagsma and D. Schaap: Collapse resistance of submarine lines studied, Oil \& Gas Journal, Feb. 2 (1981), pp. 86 95.

10) P.E. de Winter: Deformation capacity of steel tubes in deep water, OTC 4035, Offshore Technology Conference (1981), pp. $257 \sim 265$.

11) S. Kyriakides and P.K. Shaw: Response and stability of elastoplastic circular pipes under combined bending and external pressure, Int. J. Solids Structures, Vol. 18 (1982), pp. $957 \sim 973$.

12）藤田, 野本, 仁保: 防撓板の王縮強度について, 日本造船学会論文集, 第 141 号 (1977.6)，190～ 197.
13) B. D. Reddy: An experimental study of the plastic buckling of circular cylinders in pure bending, Int. J. Solids Structures, Vol. 15 (1979), pp. 669 683.

14) D. B. Brush and B. O. Almroth: Buckling of Bars, Plates and Shells, McGraw-Hill (1975).

15）加藤, 福知: 板要素の变形能力について, 日本建 築学会論文報告集, 第 147 号 (昭和 43 年 5 月), pp. $19 \sim 25$.

16) S.C. Haagsma: Research and tests study collapse of subsea pipelines, Oil \& Gas Journal, Nov. 1 (1976), pp. 54 62.

17) S. Kyriakides and C. D. Babcock: Experimental determination of the propagation pressure of circular pipes, Trans. ASME, Vol.103, Nov. (1981), pp. 328 336. 